THE INTERNATIONAL

REVIEW OF RESEARCH IN

OPEN AND DISTANCE LEARNING

\title{
ODL and the Impact of Digital Divide on Information Access in Botswana
}
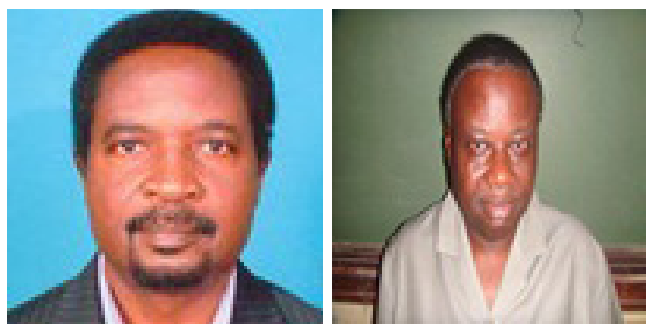

Olugbade Oladokun, University of Botswana Lenrie Aina, University of Ilorin, Nigeria

\section{Abstract}

Open and distance learning (ODL) has created room for the emergence of virtual education. Not only are students found everywhere and anywhere undertaking their studies and earning their degrees, but geographical boundaries between nations no longer appear to have much relevance. As the new education paradigm irretrievably alters the way teaching and learning is conducted, the application of modern educational ICTs has a major role to play.

With students of transnational or cross-border education dispersed into various nooks and crannies of Botswana, many others enlist for the "home-baked" distance learning programmes from their diverse locations. Like the face-to-face conventional students, distance learners also have information needs which have to be met. But blocking the distance learners' realization of their information needs is the digital divide, which further marginalizes the underclass of "info-poor."

The survey method was used, and a questionnaire administered to 519 students of four tertiary level distance teaching institutions that met the criteria set for the study yielded a 70.1\% response rate. The results showed that while the Government of Botswana has made considerable effort to ensure country-wide access to ICT, which now constitutes an effective instrument for meeting information needs, a number of problems still exist. The factors impeding easy access are unearthed. The findings of an empirical study portraying some learners as information-rich and others as information-poor, and the consequence of distance learners studying on both sides of the digital divide, are discussed. Suggestions on 
bridging the digital divide are offered.

Keywords: Distance learners; cross-border students; digital divide; information environment; ICTs; library/librarian; Internet service providers (ISP); data service providers (DSP); information literacy skills (ILS); online

\section{Introduction}

Historically, learning took place within the classroom or facility of a school or an institution where the student and his teacher met face-to-face. But the advent of distance education has significantly altered the pattern, with the result that learning can now take place with the help of some media, usually print, when the teacher and student are separated. Today, the new digital world has made the delivery of virtual education and training possible. With the development of information and communication technologies and their application to education and training, not only are distance learners increasingly found everywhere and anywhere undertaking their studies and earning their degrees, but the geographical boundaries between nations no longer pose difficulties or inhibit learners' access to education from institutions outside their countries of abode.

As in many other countries across the world, the thirst for education in Botswana has led people to search and register for distance education programmes not only with the University of Botswana but also with some institutions outside the country. In this study, those who have registered for their distance programmes in Botswana are referred to as homebased, while the cross-border students are those who have registered with institutions outside Botswana but are working or living in Botswana.

The doubts of some authors regarding distance education have revolved around how distance learners would gain access to information resources and services and meet their information needs. It has always been known that information support services are a part of higher education programmes that add to the value and quality of learning. This is why Appleton (1997) suggests that access to quality information resources and services is a critical factor in any academic programme of merit. In their perception of the library as an information provider, Kascus and Aguilar (1988) affirm that library support is an integral part of quality education and a vital service that should be available to all students, whether on-campus or off-campus. While the library is an important information source, the information environment of distance learners extends beyond it. The demands of the contemporary distance learning environment require the application and use of digital contents obtainable from or via the Internet, and other media such as radio/television, telephones, and other computer or electronic devices that can be used when the library is not available.

In Botswana, government policy on information and communication technologies is to create a favourable information environment for the people. It is reasonable to assume that when these policy goals are translated into action, the dispersed distance learners especially will benefit tremendously. Hall and Lewin (2005, p. 86) observe that the Government of Botswana, in its recognition of the importance of ICT to the future economic and social 
development of the country, articulates its vision as follows:

Botswana will be a global competitive knowledge and information society where lasting improvement in social, economic and cultural development is achieved through effective use of information and communications technology.

In clear terms, Hall and Lewin (2005) articulate the ICT guiding principle of the Government of Botswana when they declare the following goals:

1. to create an enabling environment for growth of ICT in the country;

2. to provide universal service and access to information and communications facilities in the country with, for example, an Internet access point in every village; and

3. to make Botswana into a regional ICT hub so as to make the country's services sector globally competitive. ( p. 86)

The efforts of the Government of Botswana to ensure countrywide access to ICT can be seen in the liberalization of telecommunications services and the breaking of the monopoly of Botswana Telecommunications Corporation (BTC) when mobile telephony licensing was awarded to two private companies in 1998. Sebusang, Masupe, and Chumoi (2005) also indicate that "the subsequent licensing of other service providers such as Internet service providers (ISPs), data service providers (DSPs) and private telecommunications networks (PTNs) has added to the overall growth of the sector." The introduction of the PTNs and ISPs, among other steps, is seen as part of the effective design to help people in Botswana, including distance learners, to meet their information needs. Further, using seven countries, namely Estonia, Malaysia, Mauritius, Namibia, South Africa, Trinidad and Tobago, and Canada as relevant ICT benchmarks, Botswana developed an ICT policy covering the following major areas: ICTs in homes and communities, ICTs in healthcare, ICTs in the marketplace and ICT sector, ICTs in government, ICT-enabling infrastructure, and ICTenabling legislation (Government of Botswana, 2004, pp. 1-2). This is probably why Little and Bose (2004, p. 14) exclaim that Botswana "is already an active participant in the global information society." As if to lend credence to the assertion, Mogotlhwane (2008, p. 247) noted that the employees of the Government of Botswana have access to computers and fairly fast networks by African standards, as well as ICT skills. He regrets, however, that despite this, there are still information flow delays that lead to long waits and hence customer dissatisfaction. In light of the commitment of the Government of Botswana to ensure countrywide access to ICT, the hypothesis that the digital divide has been narrowed and the tyranny of distance often experienced in open and distance learning curtailed by the environment created for the growth of ICT could be tested. 
One problem that seems to confront and impinge on not only Botswana's but the world's information environment is the issue of digital divide.

In defining the concept of digital divide, Digital Divide Network (2004) perceives the phenomenon as the gap between those who can effectively use new information and communication tools, such as the Internet, and those who cannot. Chen and Wellman (2003), on the other hand, define the digital divide as the multidimensional inequalities in Internet access and use, ranging from the global level down to nation states, communities, and individuals. Similarly, Fuchs and Horak (2008) posit that the digital divide refers to unequal patterns of material access to, usage capabilities of, and benefits from computer-based information and communication technologies due to certain stratification processes that produce classes of winners and losers in the information society and in terms of participation in institutions governing ICTs and society. Norris (2001, p. 68) has noted that

The chief concern about the digital divide is that the underclass of info-poor may become further marginalized in societies where basic computer skills are becoming essential for economic success and personal advancement, entry to good career and educational opportunities, full access to social networks, and opportunities for civic engagement.

The apprehensions of scholars like Cavanagh and Tucker (1997) and Daniel (1999), among others, about the problem created by the use of technologies have received reinforcement from other researchers. These authors have expressed their reservations about the observed disparity of technological development, use, and application between the two worlds. For instance, Adams (1997) confesses that one concern he personally has for the future of off-campus services involves "the drift towards increasing disparity between the technology-rich and technology-poor." He suggests that once off-campus services become technology-driven, they must stay the course. The problem he anticipates, however, is that IT is expensive, requiring, for example, microcomputers and servers, Internet connectivity, technical upgrades and software-plus staff to develop, maintain, and train users of web-based resources, and so on. Postle et al. (1997) hold the view that "technologies have the capacity to affect all students, but they appear particularly critical in their potential to address many of the problems of educational participation by rural and geographically isolated people." They further believe that technologies have the potential to have a very negative impact on equity. In citing their example to support this view, they seem to affirm the view of Adam noted above. They maintain that if too heavy a reliance is placed on "new technologies" in education without moves being made to ensure wide access to these technologies, the gap between the "haves" and "have-nots" will be further widened.

Mutula (2005), in a proposal on bridging the digital divide through e-governance, observes that the digital divide is always described in terms of the difference in the number of telephones, Internet users, or computers per head between rich and poor countries. Quoting the observation of Kenny and Fink in their study of global digital divide, he pointed out 
that the digital divide's size and importance have been overstated and that current trends suggest that it is actually shrinking, not growing. Mutula notes that Kenny and Fink's view that the digital divide is narrowing is based on the fact that over the past 25 years, telephone penetration has been increasing faster in low- and middle-income countries than in highincome countries because market saturation has been achieved in rich countries. The duo, according to Mutula (2005), pointed out that Internet usage, for example, grew by around $50 \%$ per year in high-income countries in the late 1990 s compared with $100 \%$ growth per year in low- and middle-income countries. He said the authors in their advocacy noted that the rich countries were ahead but that poor countries were also catching up very fast. Along with other authors like Nua (2002), Mutula (2005) observes that the digital divide in developing countries in general and Africa in particular is closely tied to the contextual economic environment of the respective countries. As if to defend the position of Botswana, Mogotlhwane (2008, p. 249) declares that Botswana faces unique challenges, mainly because it is a consumer country. He observes that in the modern globalised world, successful countries are those that produce goods and services for the globalised market and concludes that Botswana as a consumer country lies on a fragile borderline. In dismissing the opinion that the digital divide is shrinking, Van Dijk (2005, p. 50) declares:

The argument that the digital divide is shrinking, as the lowest categorical values are expanding at a higher rate than the highest values, is misleading. . . . When a developing country increases its Internet access rate from $0.1 \%$ to $2 \%$ while a developed country climbs from $20 \%$ to $40 \%$, the expansion rate of the developing country is 10 times as high as that of the developed country. However, it is much more telling in this case that the point change of the developed country is much larger. Many more new Internet users have been added.

Norris (2001) has earlier argued that once countries became affluent enough, Internet access would follow along with connectivity. The problem would be that for many countries affordability would not be possible due to social inequality. Mutula (2005) expresses the view that the issue of digital divide in Africa manifests itself in various ways. A collaborative study he did with a Fulbright Scholar from Union College, New York on the satisfaction level of students using the Internet at the University of Botswana revealed that bandwidth was a major problem. He observed that the system tray of his office computer at the University of Botswana displayed a constant access speed of $10 \mathrm{Mpbs}$. In contrast, the same reading on the Fulbright Scholar's office computer at Union College was a constant access speed of $100 \mathrm{Mbps}$, ten times faster, although it measured only the interval between the personal computer and the final router or switching point to which it was connected.

Awareness of the above challenges notwithstanding, this study set out to examine the following questions:

1. To what extent do distance learners use ICTs in meeting their information needs in 
Botswana?

2. How do distance learners in Botswana access information resources and services?

3. How adequately are distance learners in Botswana equipped to utilize the information resources and services available in their environment?

In developing the theoretical concept for this study, Norris's (2001, p. 4) description of the digital divide as a multidimensional phenomenon is considered apposite. Norris possibly has the remoteness of distance learners and cross-border students in mind when she proposes three types of digital divide: social (within countries), global (between countries), and democratic (between those able and those unable to use ICTs to take part in public life). Social divide is further signified by the gap between information-rich and information-poor in each nation. It also explains the income gap, which makes the difference between those who can afford computer and Internet access and those who cannot; global divide is signified by divergence of Internet access levels between industrialized and developed societies; and democratic divide is signified by the difference between those who do, and do not, use the opportunities of digital resources to engage, mobilize, and participate in public life. In a similar vein, the argument of Wilson (2006) on eight aspects of digital divide is found beneficial and therefore incorporated. These, according to Wilson (2006) include physical access (access to ICT devices), financial access (cost of ICT services relative to annual income), cognitive access (ICT skills), design access (usability), content access (availability of relevant applications and information online), production access (capacity to produce one's own content), institutional access (availability of institutions that enable access), and political access (access to the governing institutions where the rules of the game are written).

\section{Methods of Study}

The survey method was used for this study, and research design was both qualitative and quantitative. The four distance teaching institutions that met the criteria set for the study were the University of Botswana (UB), the University of Derby (UD), the University of South Africa (UNISA), and the Management College of Southern Africa (MANCOSA), the last three being cross-border institutions in Botswana. The empirical element of the study was conducted using the questionnaire as instrument. With a $20 \%$ sample size randomly selected from institutions with 500 or more students, University of Botswana and University of South Africa qualified, while the census method was applied to the UD and MANCOSA, which had 100 or fewer students in Botswana. A total of 519 of 1,996 (total population) became the sample size. With 364 copies of the questionnaire returned, the response rate was $70.1 \%$. Data abstracted were analysed using the SPSS program. Cross-tabulations and chi-square, non-parametric statistical significance tests were developed to test the relationship of one variable to groupings of others. 


\section{Results}

\section{Use of ICTs to Meet Distance Learners' Information Needs}

In order to address the research question "To what extent do distance learners use ICTs in meeting their information needs in Botswana?” a series of questions was generated. First, participants were asked if they had access to a computer with Internet facilities. The result shows that a total of 287 respondents (78.8\%) indicated they had access to a computer with Internet facilities, while the remaining 77 respondents (21.2\%) indicated they had no access. The relationships between location of respondents and access to a computer with Internet facilities were cross-tabulated and chi-square tests performed on the cross-tabulations. The test shows that location was significantly related to access to a computer with Internet facilities $\left(X^{2}=21.681, d f=2, p<.05\right)$.

Table 1 shows the expected and observed counts in the cross-tabulation of location and Internet accessibility by distance learners. Comparison of the observed with the expected counts shows that the observed values are significantly different from the expected values and that more respondents in the city and town than expected said "yes" to having access to a computer with Internet facilities, while fewer respondents than expected said "yes" in the village. Therefore the conclusion is that there is a significant relationship between location and access to the Internet. A number of subsequent tests also confirmed the prevalence of Internet accessibility in the city and town compared to the village. The findings confirm that the village is shortchanged when the use of and accessibility to information and communication technology in Botswana is considered. This seems to be a reflection of Wilson's physical access view (access or non-access to ICT devices) and possibly an indication of Norris's social divide hypothesis that location may create or foster information-rich or informationpoor environments. The learners in rural areas are affected. Adequate arrangement should be made for the provision of ICT facilities like the Internet in some strategic locations including the villages if distance learners working or living in such locations are to maximally benefit from ICTs. The impact of the Maitlamo project (Government of Botswana, 2004) is yet to be fully felt in rural locations.

Table 1

Location and Access to Computer with Internet Facilities

\begin{tabular}{|l|l|l|c|c|c|c|}
\hline \multirow{2}{*}{} & & & \multicolumn{2}{|l|}{$\begin{array}{l}\text { Access to computer with Inter- } \\
\text { net facilities }\end{array}$} & \\
\hline & & & & & \\
Tes of \\
Location & City & Observed count & $187(83.1 \%)$ & $38(16.9 \%)$ & 225 & 61.8 \\
\hline & & Expected count & $177.4(78.8 \%)$ & $47.6(21.2 \%)$ & 225.0 & 61.8 \\
\hline & Town & Observed count & $51(87.9 \%)$ & $7(12.1 \%)$ & 58 & 15.9 \\
\hline
\end{tabular}




\begin{tabular}{|l|l|l|c|c|c|c|}
\hline & & Expected count & $45.7(79.8 \%)$ & $12.3(21.2 \%)$ & 58.0 & 15.9 \\
\hline & \multirow{2}{*}{ Village } & Observed count & $49(60.5 \%)$ & $32(39.5 \%)$ & 81 & 22.3 \\
\hline & & Expected count & $63.9(78.9 \%)$ & $17.1(21.1 \%)$ & 81.0 & 22.3 \\
\hline \multirow{2}{*}{ Total } & & Observed count & $287(78.8 \%)$ & $77(21.2 \%)$ & 364 & 100 \\
\hline & & Expected count & $287.0(78.8 \%)$ & $77.0(21.2 \%)$ & 364.0 & 100.0 \\
\hline
\end{tabular}

A follow-up question sought to establish where respondents would have access to the Internet if the response was in the affirmative. As shown in Figure 1 below, those who indicated they had access to the Internet at work on their own computer made up 45.6\%; on their own machine at home, 22.5\%; at work on a shared machine, 20.9\%; and at home on a shared machine, $6.3 \%$. In addition to the above, 28 other respondents specified other Internet access points they used. These include Internet café (6.0\%), friend's office (0.3\%), and other libraries (1.6\%).

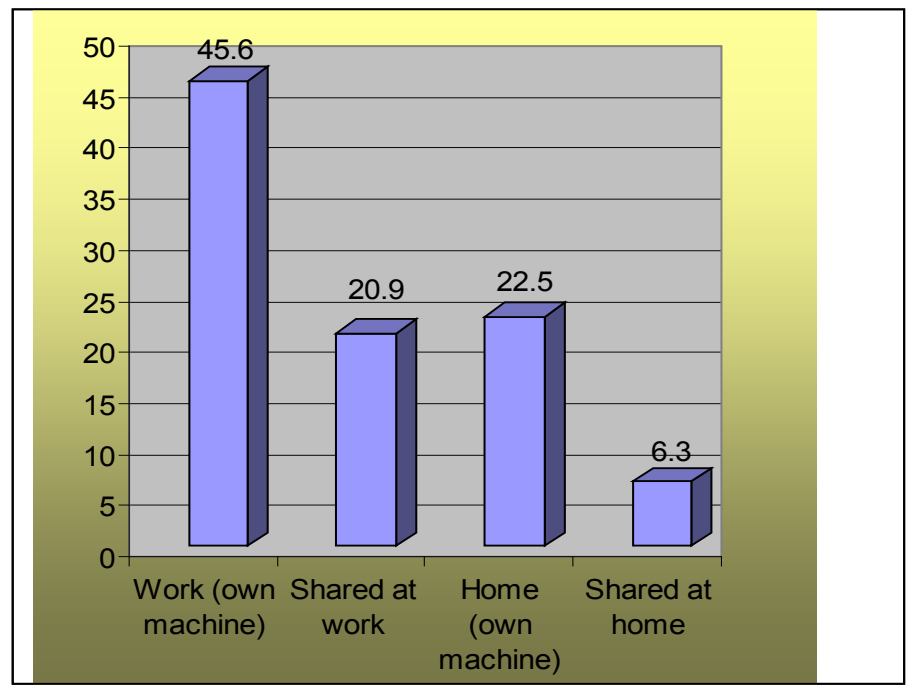

Figure 1. Internet access points.

The relationships between the institutions of respondents and access to a computer with Internet facilities were cross-tabulated and chi-square tests performed on the cross-tabulations. The test shows that institution was significantly related to access to a computer with Internet facilities $\left(X^{2}=13.359, d f=3, p<.05\right)$.

Table 2 shows the expected and observed counts in the cross-tabulation of Institution and Internet accessibility by distance learners. Comparison of the observed with the expected counts shows that the observed values are significantly different from the expected values and that more respondents from all the cross-border institutions than expected said "yes" to having access to a computer with Internet facilities, while fewer respondents than expected said "yes" in the UB (home-based institution). Therefore the conclusion is that there is a significant relationship between Institution and access to the Internet. It can also be concluded that, possibly because most of the cross-border institutions are involved in running postgraduate programmes, the respondents from those institutions were much more 
gainfully employed and therefore had more opportunity to access a computer with Internet facilities. This tends to indicate the strength of the cross-border students in financial access, which was cited earlier in Wilson's argument. Also reflected are Wilson's design access (usability) and content access (availability of relevant applications and information online), as well as institutional access (availability of institutions that enable access). The result also seems to have some bearing on Norris's global (between countries) type of digital divide. Though a number of subsequent tests revealed that accessibility to the Internet was facilitated mostly in respondents' places of work, there was sufficient evidence to show that family resources facilitated accessibility of some respondents. Thus, Norris's social divide, which differentiates between those who can afford computer and Internet access and those who cannot, was verified. See details in Figure 2 below.

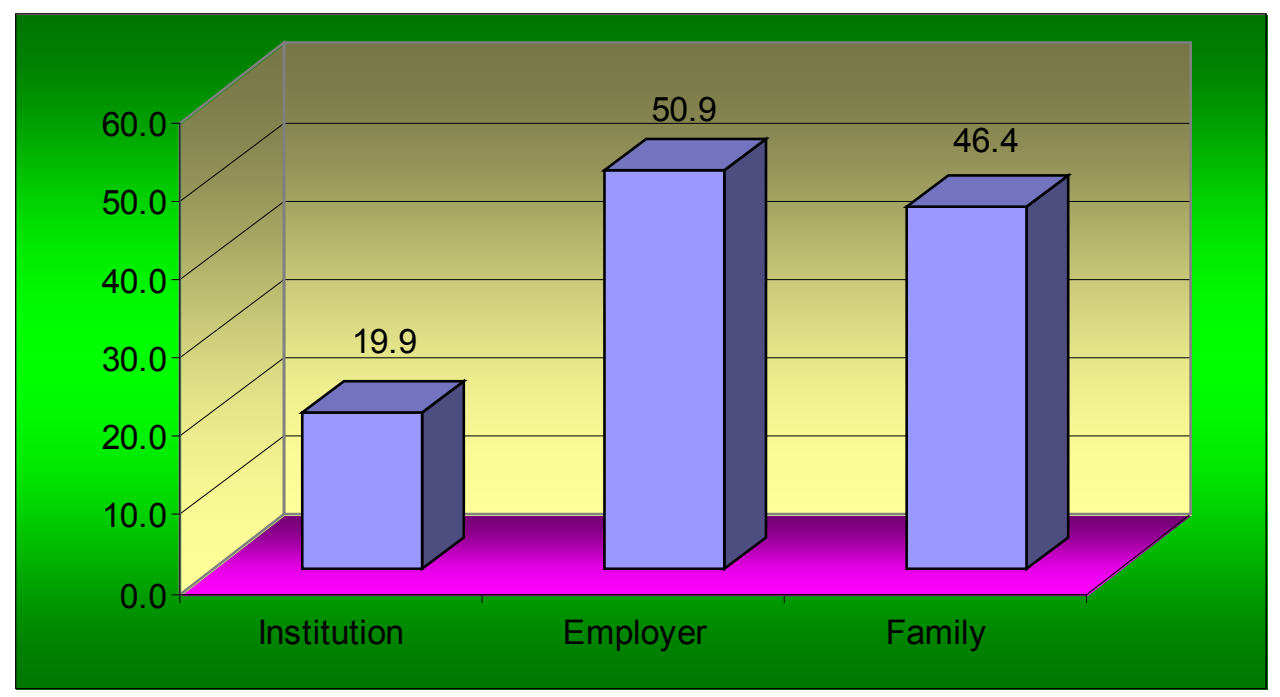

Figure 2. Who pays the cost of using the Internet?

Table 2

Institution and Access to Computer with Internet facilities

\begin{tabular}{|c|c|c|c|c|c|c|}
\hline & & \multicolumn{2}{|c|}{$\begin{array}{l}\text { Access to computer with In- } \\
\text { ternet facilities }\end{array}$} & \multirow[b]{2}{*}{ Total } & \multirow{2}{*}{$\begin{array}{l}\% \text { of } \\
\text { total }\end{array}$} \\
\hline & & & Yes & No & & \\
\hline \multirow[t]{2}{*}{ Institution } & $\begin{array}{l}\text { UB } \\
\text { (Home-based) }\end{array}$ & Count & $66(67 \cdot 3 \%)$ & $32(32.7 \%)$ & 98 & 26.9 \\
\hline & & Expected count & 77.3(78.9\%) & $20.7(21.1 \%)$ & 98.0 & 26.9 \\
\hline
\end{tabular}




\begin{tabular}{|c|c|c|c|c|c|c|}
\hline & $\begin{array}{l}\text { UNISA } \\
\text { (Cross-bor- } \\
\text { der) }\end{array}$ & Count & $128(81 \%)$ & $30(19 \%)$ & 158 & 43.4 \\
\hline & & Expected count & $124.6(78.9 \%)$ & $33.4(21.1 \%)$ & 158.0 & 43.4 \\
\hline & $\begin{array}{l}\text { MANCOSA } \\
\text { (Cross-bor- } \\
\text { der) }\end{array}$ & Count & $36(80 \%)$ & $9(20 \%)$ & 45 & 12.4 \\
\hline & & Expected count & $35.5(78.9 \%)$ & $9.5(21.1 \%)$ & 45.0 & 12.4 \\
\hline & $\begin{array}{l}\text { UD } \\
\text { (Cross-bor- } \\
\text { der) }\end{array}$ & Count & $57(90.5 \%)$ & $6(9.5 \%)$ & 63 & $17 \cdot 3$ \\
\hline & & Expected count & $49.7(78.9 \%)$ & $13 \cdot 3(21.1 \%)$ & 63 & 17.3 \\
\hline \multirow[t]{2}{*}{ Total } & & Count & $287(78.8 \%)$ & $77(21.2 \%)$ & 364 & 100 \\
\hline & & Expected count & $287.0(78.8 \%)$ & $77.0(21.2 \%)$ & 364.0 & 100.0 \\
\hline
\end{tabular}

Another question asked if the respondents use the Internet or any other electronic database to supplement their reading or writing of assignments. A total of 291 respondents (79.9\%) indicated "yes," while 73 (20.1\%) said "no." Other ICTs in use as indicated by respondents include email (46.2\%) ( $n=168)$, WebCT (27.7\%), and online databases/sources $(28.8 \%)$. Email was seen to be a satisfying information source by $31.9 \%$ of respondents.

\section{Access to Information Resources and Services by Distance Learners}

Another research goal was to establish how distance learners in Botswana access information resources and services. In order to address the issue, the respondents were asked a number of questions, ranging from how they received library and information support services to whether their institution provided them adequate library and information service to how they contacted their library/subject librarian. Information was also sought on the use of the Internet (electronic sources) and who paid the cost of using the facility. Respondents were also asked if they accessed their institutional library Web site and how often, if yes.

With respect to how the respondents received library and information support service, most of them (45.9\%) indicated "buying their own materials" as the major source. In other words, a significant number of the respondents accessed information from materials (books) they bought on their own. In order to access information resources and services, $40.9 \%$ of respondents also personally traveled to their institution's library. Those who indicated that they accessed or received library and information support through online or electronic supply comprised $32.7 \%$ and those who accessed or received library and information support 
through collaboration with some libraries and information centres comprised $27.5 \%$. It is remarkable to note that $26.6 \%$ indicated that they received support service by asking for help from knowledgeable people. Less than a quarter of the respondents (22.0\%) indicated that they received the support service through direct supply by post from their institution's library. Figure 3 provides some details at a glance. It is also important to note that quite a substantial number (57\%) indicated that their institutions did not provide them with adequate library and information support. Hence, they accessed information resources and services through other libraries. As indicated, libraries the distance learners used include the University of Botswana (UB) main library (40.7\%), UB branch library (28.6\%), public library (31.6\%), colleges of education (8.5\%), and other institutional libraries within the country (9.6\%).

The relationships of the institution with other libraries used by the respondents were crosstabulated and chi-square tests were performed on the cross-tabulations. The result shows that Institution was significantly related to the UB main library $\left(X^{2}=12.476, d f=3, p<\right.$ .05), UB branch library $\left(X^{2}=13.662, d f=3, p<.05\right)$, and public library $\left(X^{2}=11.522, d f=3\right.$, $p<.05$ ) in terms of libraries used. Further details show that a large number of cross-border students used or accessed information at the UB main and branch libraries.

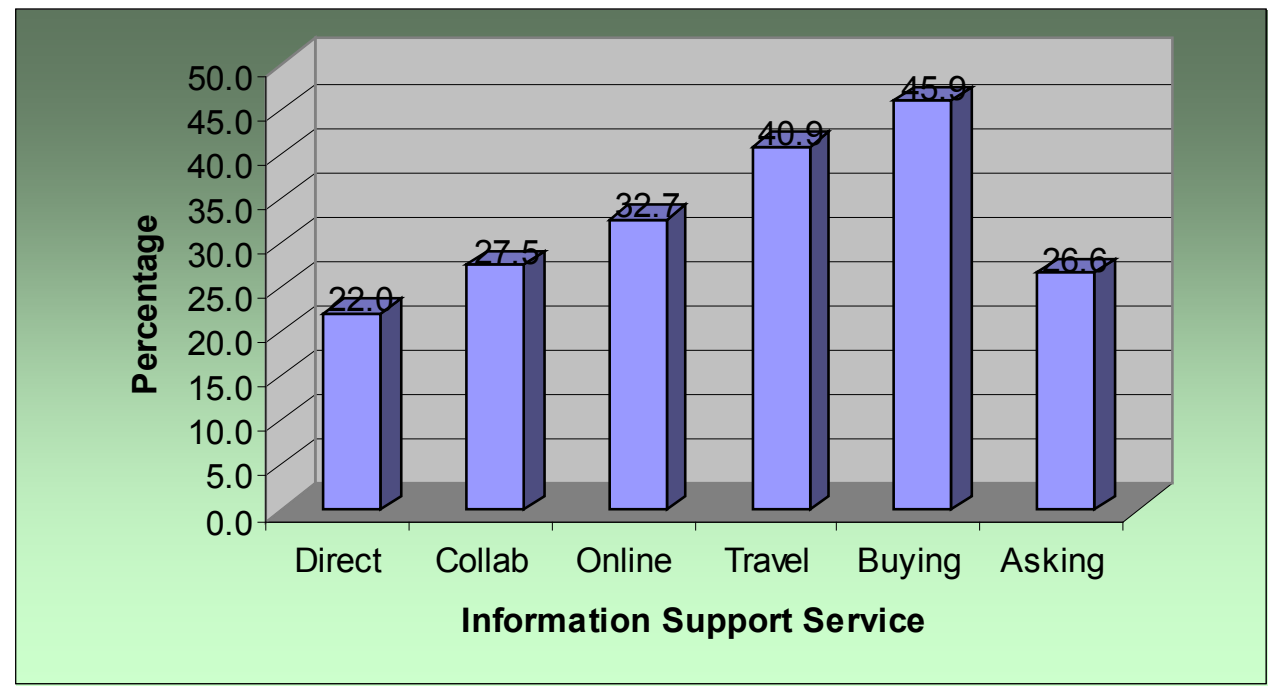

Figure 3. How students access information resources and services.

In accessing information resources and services, it was expected that students would contact library and/or subject librarians. On inquiring into how they contact the library or subject librarian to meet their information needs, a majority of respondents, 193 (53\%) indicated they visited the library/subject librarian in person. Regrettably, about a third of the respondents, 120 (33\%) said they maintained no contact either with the library or any subject librarian. Getting in touch with the library or subject librarian through email facilities attracted 73 respondents (20.1\%). Less than $5 \%$ made use of other options. In descending order, writing/posting a letter and getting in touch through facsimile had 16 respondents (4.4\%) each; only 13 respondents (3.6\%) claimed they used a toll-free telephone number, while only 12 (3.3\%) used Short Message Service (SMS), often called text messaging, with a 
cell/mobile phone. An insignificant few, only 7 respondents (1.9\%), left messages on a telephone answering machine. Figure 4 shows the different means through which the distance learners contacted the library or subject librarian.

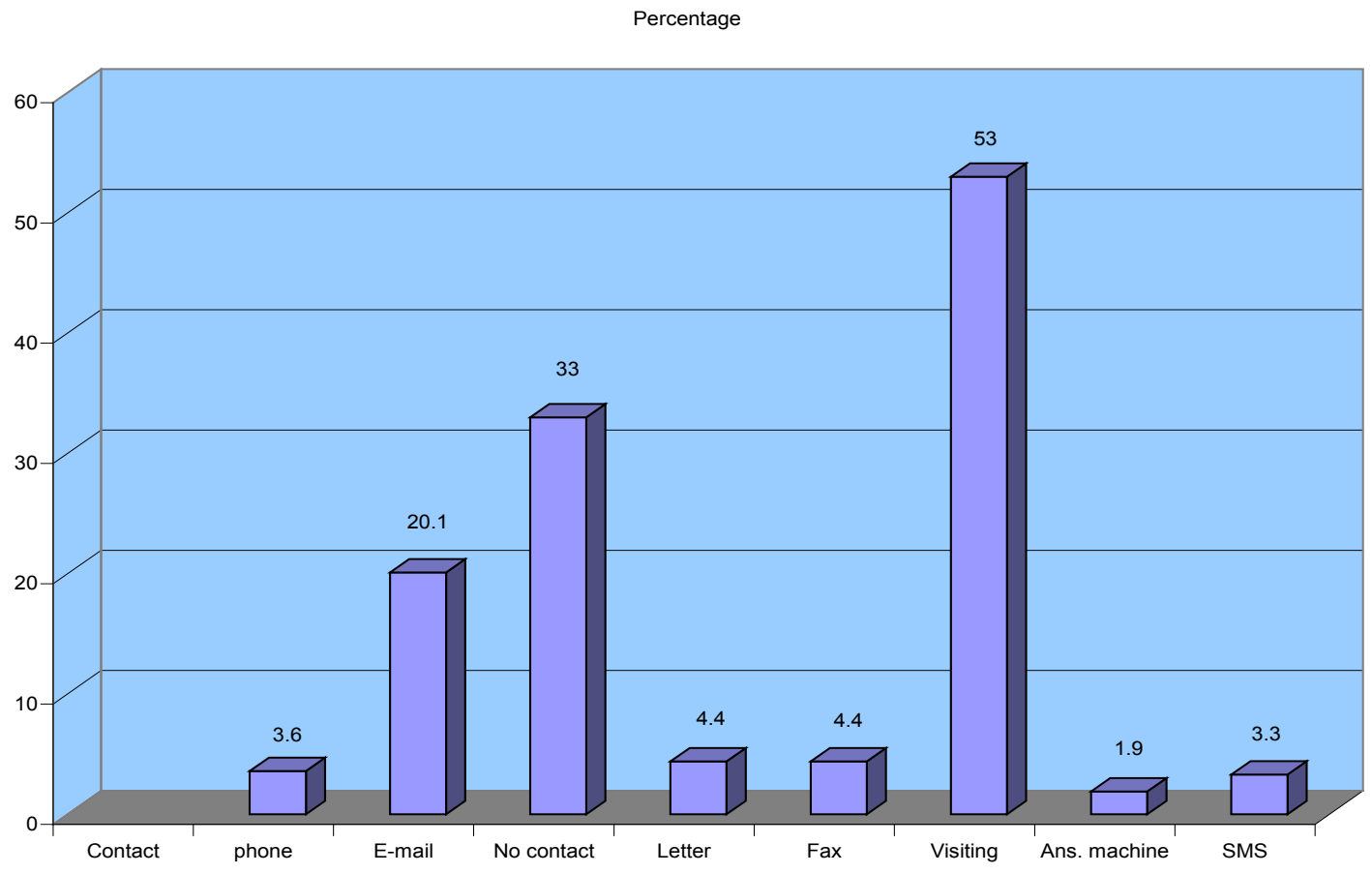

Figure 4. Contacting library/subject librarian.

As to whether they accessed their institutional library Web site, $52.2 \%$ responded in the affirmative and $39.3 \%$ in the negative. The relationships between location and accessing the institutional library Web site by distance learners were cross-tabulated and chi-square tests performed on the cross-tabulations. The test shows that location was significantly related to accessing their respective institutional libraries $\left(X^{2}=12.408, d f=2, p<.05\right)$.

Table 3 shows the expected and observed counts in the cross-tabulation of various locations (city, town, and village) of distance learners and whether they accessed their respective institutional library Web sites. Comparison of the observed with the expected counts shows that the observed values are significantly different from the expected values and that more respondents in the city than expected said "yes," while fewer respondents than expected said "yes" in the village. In the town, the number observed was about the number expected. Notwithstanding the outcome of the town results, the conclusion is that there is a significant relationship between location and accessing the Web site of their institutional libraries. The findings still substantiate the fact that the village and the city are quite different with respect to the use of and accessibility to electronic database or digital contents. These also depict the social divide of Norris, the gap between the information-rich and information-poor and the democratic divide, which signifies those unable to use ICTs in order to take part in public life. The institutional library Web site, among other things, usually has a section for the online public access catalogue (opac) of the library. It is possible to make 
requests through the Web site. The opac page may also contain links to some e-journals, including full-text articles. Visiting the institutional library Web site would therefore give a hint as to how useful distance learners found the site. In this respect, the frequency or regularity of access to the institutional library Web site was examined. Of the 197 who responded to the question, 98 respondents (49.7\%) said they visited the Web site regularly, 38 (19.3\%) once a week, 17 (8.6\%) twice a month, 23 (11.7\%) once a month, and 10 (5.1\%) once in three months; 9 (4.6\%) indicated they never visited the Web sites, while 2 others indicated they visited their library Web site only when they considered it necessary.

Table 3

Location - Do you Access your Institutional Library Web Site?

\begin{tabular}{|c|c|c|c|c|c|c|}
\hline & & \multicolumn{2}{|c|}{$\begin{array}{l}\text { Do you access your institution- } \\
\text { al library Web site? }\end{array}$} & \multirow[b]{2}{*}{ Total } & \multirow{2}{*}{$\begin{array}{l}\% \text { of } \\
\text { total }\end{array}$} \\
\hline & & & Yes & No & & \\
\hline \multirow[t]{6}{*}{ Location } & City & Count & $133(63.3 \%)$ & $77(36.7 \%)$ & 210 & 63.1 \\
\hline & & Expected count & $119.8(57 \%)$ & $90.2(43 \%)$ & 210.0 & 63.1 \\
\hline & Town & Count & $29(55.8 \%)$ & $23(44.2 \%)$ & 52 & 15.6 \\
\hline & & Expected count & $29.7(57.1 \%)$ & $22.3(42.9 \%)$ & 52.0 & 15.6 \\
\hline & Village & Count & $28(39.4 \%)$ & $43(60.6 \%)$ & 71 & 21.3 \\
\hline & & Expected count & $40.5(57 \%)$ & $30.5(43 \%)$ & 71.0 & 21.3 \\
\hline \multirow{2}{*}{\multicolumn{2}{|c|}{ Total }} & Count & $190(57.1 \%)$ & $143(42.9 \%)$ & 333 & 100 \\
\hline & & Expected count & $190.0(57.1 \%)$ & $143.0(42.9 \%)$ & 333.0 & 100.0 \\
\hline
\end{tabular}

Equipping Distance Learners to Utilize Information Resources and Services

The third objective of the study was to determine if distance learners were adequately equipped to utilize the information resources and services available to them. In addressing the research question derived from the objective, a number of questions on computing and information literacy skills (ILS) training were raised with the respondents. First, when asked if they had received any training on the use of computers, 256 respondents (70.3\%) said they had received training, while another 107 (29.4\%) said they had not. Asked how the training was arranged, $58.3 \%$ indicated they received the training through their employers in their respective workplaces. Another group of $34.0 \%$ specified that they arranged the training on their own; $28.2 \%$ said they received the training through the module given to them; and 14.2\% claimed they were trained during a residential session arranged for them by their institutions. Another $0.8 \%$ indicated that they were trained in the use of computers in their previous institutions. Figure 5 provides some details. 


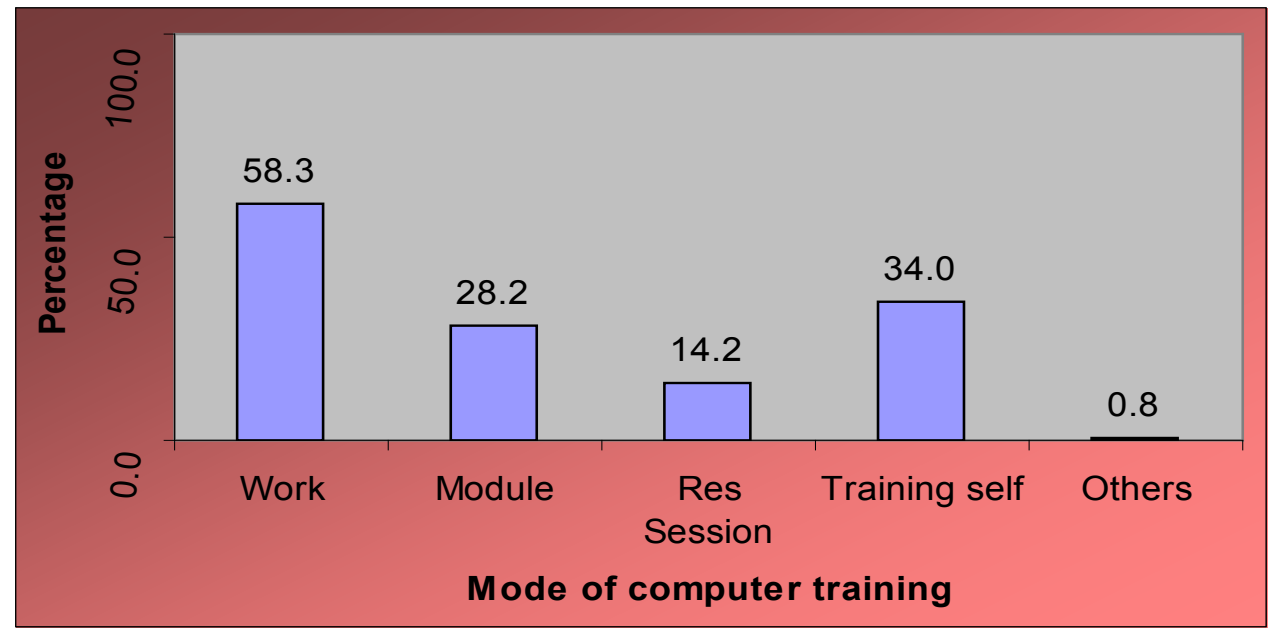

Figure 5. How computer training was received.

The relationships between the institutions of respondents and computer training were cross-tabulated and chi-square tests performed on the cross-tabulations. The test shows that the institution of respondents was significantly related to computer training $\left(X^{2}=\right.$ 16.923, $d f=3, p<.05)$.

Table 4 shows the expected and observed counts in the cross-tabulation of Institution and the computer training by distance learners. Comparison of the observed with the expected counts shows that the observed values are significantly different from the expected values and that fewer respondents from all the cross-border institutions (UNISA, MANCOSA and UD) than expected said "yes" to receiving training on the use of computers, while more respondents than expected said "yes" in the UB (home-based institution). Therefore the conclusion is that there is a significant relationship between Institution and computer training. The findings evidently imply that UB provided more computer training to its students than the cross-border institutions to their students. It seems ironic that although the cross-border students had better access to the Internet, the results showed they lacked computing skills training. This clearly confirms the cognitive access (ICT skills) aspect of the digital divide that Wilson (2006) explains. Conversely, the "home-based" students seemed to enjoy institutional access (availability of institutions that enable access). 
Table 4

Institution - Did/Do you Receive any Training on the Use of a Computer?

\begin{tabular}{|c|c|c|c|c|c|c|}
\hline & & \multicolumn{2}{|c|}{$\begin{array}{l}\text { Training received on use of } \\
\text { computer }\end{array}$} & \multirow[b]{2}{*}{ Total } & \multirow{2}{*}{$\begin{array}{l}\% \text { of } \\
\text { total }\end{array}$} \\
\hline & & & Yes & No & & \\
\hline \multirow[t]{7}{*}{ Institution } & $\begin{array}{l}\text { UB } \\
\text { (Home-based) }\end{array}$ & Count & $84(86.6 \%)$ & $13(13.4 \%)$ & 97 & 26.7 \\
\hline & & Expected count & $68.4(70.5 \%)$ & $28.6(29.5 \%)$ & 97.0 & 26.7 \\
\hline & $\begin{array}{l}\text { UNISA } \\
\text { (Cross-bor- } \\
\text { der) }\end{array}$ & Count & $101(63.9 \%)$ & $57(36.1 \%)$ & 158 & 41.6 \\
\hline & & Expected count & $111.4(70.5 \%)$ & $46.6(29.5 \%)$ & 158.0 & 41.6 \\
\hline & $\begin{array}{l}\text { MANCOSA } \\
\text { (Cross-bor- } \\
\text { der) }\end{array}$ & Count & $31(68.9 \%)$ & $14(31.1 \%)$ & 45 & 12.4 \\
\hline & & Expected count & $31.7(70.4 \%)$ & $13.3(29.6 \%)$ & $45 \cdot 0$ & 12.4 \\
\hline & $\begin{array}{l}\text { UD } \\
\text { (Cross-bor- } \\
\text { der) }\end{array}$ & Count & $40(63.5 \%)$ & $23(36.5 \%)$ & 63 & 17.4 \\
\hline & & Expected count & $44.4(70.5 \%)$ & $18.6(29.5 \%)$ & 63 & 17.4 \\
\hline \multirow{2}{*}{\multicolumn{2}{|c|}{ Total }} & Count & $256(70.5 \%)$ & $107(29.5 \%)$ & 363 & 100 \\
\hline & & Expected count & $256.0(70.5 \%)$ & $107.0(29.5 \%)$ & 363 & 100.0 \\
\hline
\end{tabular}

Acquisition of information (literacy) skills (ILS) was also considered important in equipping distance learners for effective and efficient utilization of information resources and services. Some information was therefore elicited from respondents on these skills through the questionnaire. First, the respondents were asked if their institution provided them training on information (literacy) skills. With only 2 specifying "missing system," 192 respondents (52.7\%) said "yes," while 170 of them (46.7\%) responded "no." In determining how the training was received by those who said they were trained, a number of options were presented. As shown in Figure 6, a majority of respondents (63.6\%) indicated that they received their training through the module given to them, $36.4 \%$ through face-to-face teaching during orientation, and 31.0\% through tutoring during residential sessions; $9.1 \%$ claimed they received the training by e-learning mode, while $0.01 \%$ others said the training was received from their previous institutions. 


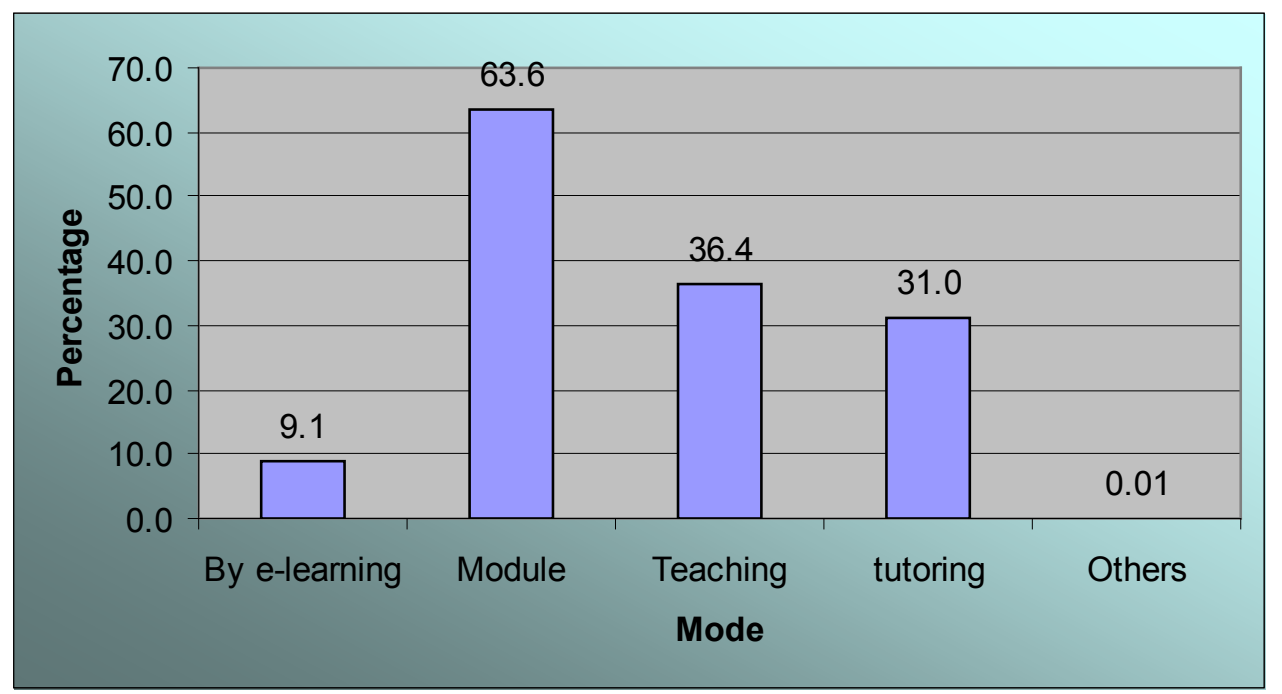

Figure 6. Mode of receiving ILS training.

The relationships between the institutions of respondents and information skills training were cross-tabulated and chi-square tests performed on the cross-tabulations. The test shows that Institution was significantly related to information skills training $\left(X^{2}=32.870\right.$, $d f=3, p<.05)$.

Table 5 shows the expected and observed counts in the cross-tabulation of Institution and information skills training of distance learners. Comparison of the observed with the expected counts shows that the observed values are significantly different from the expected values and that it was only in UB that more respondents than expected said "yes," whereas in other institutions (cross-border, including UNISA, MANCOSA, and UD) fewer respondents than expected said "yes." The conclusion, therefore, is that only the UB provided information skills training for its students and that other (cross-border) institutions did not. While the UB (home-based) could be seen in terms of Wilson's institutional access (an institution that enabled access), the results did not portray the remaining cross-border institutions as those that enabled access. 
Table 5

Institution - Did your Institution Provide Training on Information Skills?

\begin{tabular}{|c|c|c|c|c|c|c|}
\hline & & \multicolumn{2}{|c|}{$\begin{array}{l}\text { Did your institution provide } \\
\text { training on info skills? }\end{array}$} & \multirow[b]{2}{*}{ Total } & \multirow{2}{*}{$\begin{array}{l}\% \text { of } \\
\text { total }\end{array}$} \\
\hline & & & Yes & No & & \\
\hline \multirow[t]{7}{*}{ Institution } & $\begin{array}{l}\text { UB } \\
\text { (Home-based) }\end{array}$ & Count & $76(77.6 \%)$ & $22(22.4 \%)$ & 98 & 27.1 \\
\hline & & Expected count & $52.0(53.1 \%)$ & $46.0(46.9 \%)$ & 98.0 & 27.1 \\
\hline & $\begin{array}{l}\text { UNISA } \\
\text { (Cross-bor- } \\
\text { der) }\end{array}$ & Count & $67(42.7 \%)$ & $90(57.3 \%)$ & 157 & 43.4 \\
\hline & & Expected count & $83.3(53.1 \%)$ & $73.7(46.9 \%)$ & 157.0 & $43 \cdot 4$ \\
\hline & $\begin{array}{l}\text { MANCOSA } \\
\text { (Cross-bor- } \\
\text { der) }\end{array}$ & Count & $19(43.2 \%)$ & $25(56.8 \%)$ & 44 & 12.2 \\
\hline & & Expected count & $23.3(53 \%)$ & $20.7(47 \%)$ & 44.0 & 12.2 \\
\hline & $\begin{array}{l}\text { UD } \\
\text { (Cross-bor- } \\
\text { der) }\end{array}$ & Count & $30(47.6 \%)$ & $33(52.4 \%)$ & 63 & 17.4 \\
\hline & & Expected count & $33.4(53 \%)$ & $29.6(47 \%)$ & 63.0 & 17.4 \\
\hline \multirow{2}{*}{\multicolumn{2}{|c|}{ Total }} & Count & $192(53 \%)$ & $170(47 \%)$ & 362 & 100 \\
\hline & & Expected count & $192.0(53 \%)$ & $170.0(47 \%)$ & 362.0 & 100.0 \\
\hline
\end{tabular}

\section{Conclusion and Recommendations}

This study confirms that more information resources and services are available in the city than in the town or village. The results show that there is abundant evidence of the digital divide in Botswana, notwithstanding the popularized Maitlamo Project on ICT policy of the government. Accessibility to digital resources by distance learners is seen to have a locational dimension in that it is much more convenient to access information in the metropolitan areas than in rural locations. In other words, the more rural a location, the less the chance of having adequate information resources. The tyranny of distance is still a serious factor to learners who, for any reason, are located outside the city. The development of disparity as a result of the location of individuals has been observed by Slade (1997). Slade regrets that "we may see a class system developing among distance learners" and also that 
"urbanites will have high-speed connections to the World Wide Web and ready access to information resources" in contrast to rural students. Slade (1997) predicts that students located in rural areas will remain dependent on local libraries or a library delivery service from campus until such time as it is economically feasible for cable or telephone companies to run high-speed data transmission lines into the average household or until Internet access by satellite becomes widely available. The study reveals evidence of Cavanagh's (1997) remarks that many students still do not own (whether by choice or lack of resources) the necessary equipment to participate in the new era of instant information access.

In order to curtail the effects of the emerging class system in tertiary distance and crossborder education in Botswana and ensure that electronic access issues do not lead to even greater student isolation and that teachers are not "pushed further into becoming designers of pre-packaged programmed learning” (Stephens \& Unwin, 1997), the following suggestions are offered.

- More effort should be exerted by the Government of Botswana on its Maitlamo ICT policy and the policy implementation, especially in rural locations. Because most villages in Botswana enjoy relatively stable electricity and telephone connections, encouragement should be given to private ISPs, DSPs, PTNs, and government agencies to spread their services beyond municipalities to rural locations.

- Distance teaching institutions need to not only teach but also make computing and information literacy skills training mandatory for distance learners.

- Information resources and services should be provided through establishment of study centres in strategic locations and collaborative partnerships with viable institutions, schools, or public libraries.

- Adequate utilization of cell phone functionalities should be encouraged.

- The use of modern ICTs such as email, facsimile, and telephone answering machine should be encouraged.

- Services available for DLs, including the use of librarians and help/reference desks, should be adequately promoted.

- Although the information world is increasingly digital, the distance learning environment in Botswana is still largely print-based, and this should be respected. 


\section{References}

Adams, C. (1997). The future of library services for distance education: What are we doing, where are we heading, what should we be doing? Journal of Library Services for Distance Education, 1 (1). Retrieved from http://www.westga.edu/ library/jlsde/ vol1/1/CAdams.html

Appleton, M. (1997). Reaching the remote student. In E. F. Watson \& N. Jagannathan (Eds.), Library services in the Commonwealth: A reader. Vancouver: The Commonwealth of Learning.

Cavanagh, A. K. (1997). Library services for off-campus students: At the crossroads? Journal of Library Services for Distance Education, 1(1). Retrieved from http://www. westga.edu/ library/jlsde/vol1/1/TCavanagh.html

Cavanagh, A. K., and Tucker, J. (1997). A library service to distance learners: What should the library provide? In E.F. Watson \& N. Jagannathan (Eds.), Library services in the Commonwealth: A reader. Vancouver: The Commonwealth of Learning.

Chen, W. and Wellman, B. (2003). Charting and bridging digital divides: Comparing socio-economic, gender, life stage, and rural-urban internet access and use in eight countries. NetLab Centre for Urban and Community Studies, University of Toronto. Retrieved from http://www.amd.com/us-en/assets/content_type/DownloadableAssets/

Daniel, J. (1999). Distance learning in the era of networks: What are the key technologies? Keynote address delivered at Pan Commonwealth Forum on Open learning: A celebration of ten years of the Commonwealth of Learning in Brunei, March 1-5, 1999, pp. 1-10

Digital Divide Network. (2004). Digital Divide Basics. Retrieved from www.digitaldividenetwork.org/content/sections/index.cfm?key=2

Fuchs, C. and Horak, E. (2008). Africa and the digital divide. Telematics and Informatics, 25(2), 99-116. Retrieved from http://www.sciencedirect.com/science/article/pii/ So736585306000359\#bbib25

Government of Botswana. (2004). Maitlamo Botswana's National ICT policy: Legislative framework and change report. Retrieved from http://www.bits.org.bw/downloads/MAITLAMO_NATIONAL_ICT_POLICY.pdf

Hall, R. and Lewin, D. (2005). A final report to the Botswana Telecommunications Authority: ICT policies and liberalization. Retrieved from http://www.bta.org.bw/pubs/ final\%20report\%20\%20-\%20liberalisation.doc

Kascus, M. and. Aguilar, W. (1988). Providing library support to off-campus programmes. 
College and Research Libraries 49(1), 29-37.

Little, D. and Bose, A. (2004). Maitlamo, National E-readiness Assessment Vol. 1: E- readiness, Executive Draft, Botswana National ICT Policy. Gaborone: Department of Information Technology.

Mogotlhwane, T. M. (2008). Barriers to successful application of information technology in Botswana (Doctoral dissertation). University of Salford. Retrieved from http:// usir.salford.ac.uk/1735/1/Mogotlhwane_Thesis.pdf

Mutula, Stephen M. (2005) Bridging the digital divide through e-governance: A proposal for Africa's libraries and information centres. Electronic Library, 23(5), 591-602.

Norris, P. (2001). Digital divide: Civic engagement, information poverty and the Internet worldwide. Cambridge: Cambridge University Press. Retrieved from http://ksghome.harvard.edu/ pnorris/acrobat/digitalch4.pdf

Nua (2002). Internet survey by area. Retrieved from http://www.nua.com/surveys/

Postle, G. D., et al. (1997). Towards excellence in diversity: Educational equity in the Australian Higher Education sector in 1995: Status trends and future directions. Toowoomba, Queensland: USQ Press.

Sebusang, S., Masupe, S., and Chumoi, J. (2005). Botswana. In A. Gillwald (Ed.), Towards an African e-Index: Household and individual ICT access and usage across 10 African countries. Retrieved from http://www.researchictafrica.net/images/upload/Chaptero3Botswana.pdf

Slade, A. L. (1997). Some observations on the future of library services for off-campus and distance education. Journal of Library Services for Distance Education, 1(1). Retrieved from http://www.westga.edu/ library/jlsde/vol1/1/ASlade.html

Stephens, K., and Unwin, L. (1997). The heart of the matter: Libraries, distance education and independent thinking. Journal of Library Services for Distance Education, 1(1). Retrieved from http://www.westga.edu/ library/jlsde/vol1/1/KStephens_ LUnwin.html

Van Dijk, J. (2005). The deepening divide: Inequality in the information society. London: Sage

Wilson, E. J. (2006). The information revolution and developing countries. Cambridge, MA: MIT Press. 


\section{Athabasca University $\mathbf{Z}$}

(c) () 